\title{
Geokongres i Norge en succes - over 6.000 deltagere fra hele Verden
}

\section{Af geolog Ulla V. Hjuler, GeologiskNyt}

Lillestrøm ved Oslo var vært for flere end 6.000 deltagere i perioden 6. til 14. august, og konferencen, der var den 33. i rækken, blev en

Det var en stor udfordring at få logistikken for foredrag, konferencer, poster sessions og meget andet til at fungere. Men det lykkedes!

\section{Imponerende statistik}

Ved kongressens afslutning kunne arrangørerne begynde at kigge nærmere på statistikken - og den var ganske interessant.

Af de 6.260 deltagere var norske deltagere repræsenteret med ikke færre end 920 deltagere, Rusland var den fjerde største at så mange havde fravalgt De Olympiske Lege i deres hjemland for at hellige sig geologien! Endelig var der som den femte mest repræsenterede nation Italien med 267 deltagere.

113 nationer deltog med 6.300 præsenet meget varieret udvalg af ekskursioner før, under og efter kongressen - hele 37 ekskursioner til de nordiske lande, Rusland Ukraine mv. I alt deltog 664 personer på ekskursionerne.

Undervejs blev der afholdt 96 forretningsmøder og 20 work shops/kurser, og sidst men ikke mindst var der udstillere fra flere lande - fra Danmark bl.a. GEUS og Mærsk. Undervejs kunne deltagerne desuden lade sig inspirere af geologiskt relaterede udstillinger både i Lillestrøm i selve kongresområdet og i Oslo. stor succes. nation med 505 deltagere, USA med 394 og Kina med hele 376 deltagere. Imponerende tationer og 350 symposier. Desuden var der

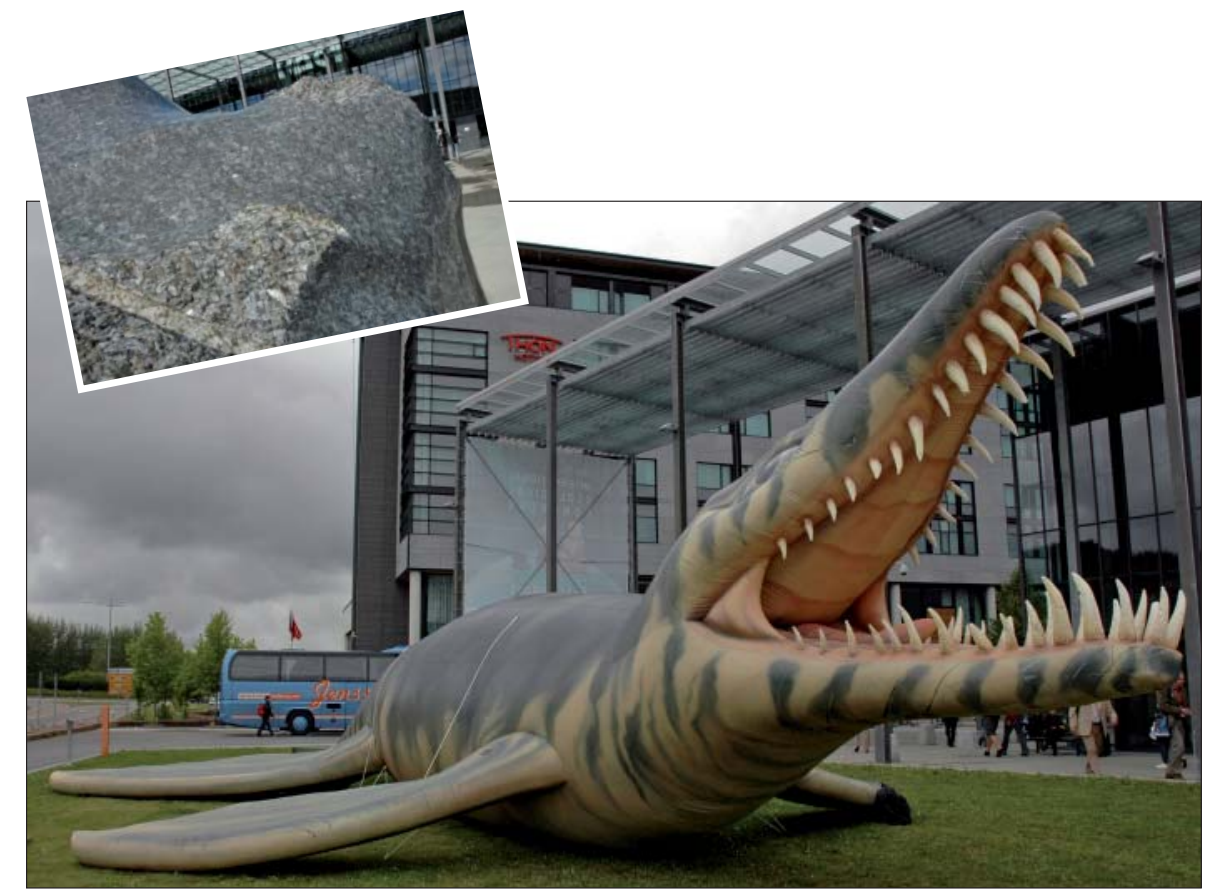

Den store, men dog ret luftige Plesiosaurus gaber uden for konferencehallerne. Øverst et udsnit af en larvikitskulptur, der også stod uden for bygningerne. (Fotos: Løvø Gudmund, NGU)

\section{Rundt om geologien}

Selvom konferencen varede 9 dage, var det selvsagt ikke muligt at nå at høre mere end en brøkdel af foredragene. Geoemner spændende fra kappe/kernedynamik over grundvandsressourcer til stratigrafisk klassifikation, lagdelte intrusioner, sporfossiler, klima og meget meget mere blev dækket.

Overordnet var der arrangeret "Dagens Tema” med følgende temaer: Biodiversitet og udvikling, Klima, “Geohazards”, Vand og helbred, Mineralressourcer, Energi samt Jorden og "det derude". Hver temadag blev afsluttet med en paneldebat, og temadagen med klima og klimaforandringer endte i en yderst ophedet debat med bl.a. Connie Hedegaard, vores klima- og energiminister, samt Henrik Svensmark, DTU Space, som paneldebattører. Debatten om klimaforandringer, og hvorvidt de er menneskeskabte

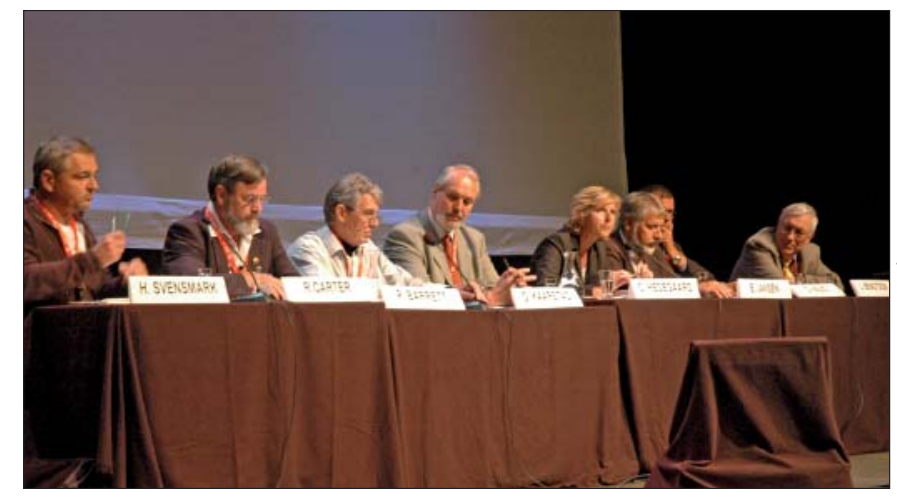

Der var ikke brug for vintertøjet under paneldebatten på klimamødet-her kunne man virkelig mcerke de omstridte temperaturstigninger. (Foto: Løvø Gudmund, NGU) eller ej, fik i sandhed temperaturen til at stige nogle grader i konferencerummet.

Temperaturen udenfor var til gengæld ikke overvældende, men der var dog solglimt ind imellem, og her kunne man bl.a. gå ud og kigge på den $15 \mathrm{~m}$ lange oppustelige Plesiosaurus, der vogtede uden for konferenceområdet - eller på en stort larvikitskulptur - larvikit er Norges nationalsten.

\section{Australien om 4 år}

Allerede nu kan geologerne godt begynde at finde badetøjet frem, for Australien er vært ved den 34. kongres i rækken - og de garanterede godt vejr også om 4 år!

Desuden blev det afgjort, at Sydafrika skal huse den 35. geokongres i 2016.

Og der bliver en del at leve op til for de to nationer, for vores nordiske nabo havde gjort et strålende stykke arbejde!

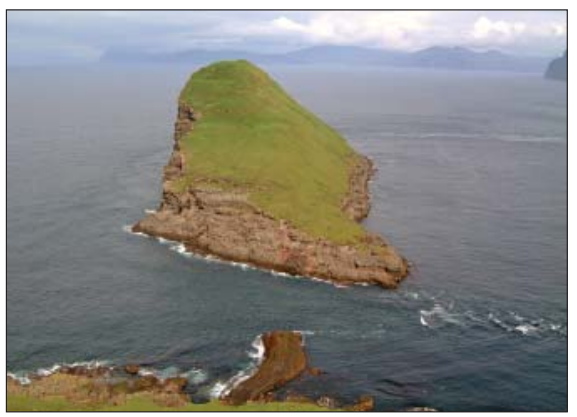

En af de mange ekskursioner fandt sted på Fœrøerne. (Foto: Løvø Gudmund, NGU) 